\title{
Recent advances in sow nutrition
}

\author{
Sung Woo Kim ${ }^{1}$ \\ ${ }^{1}$ North Carolina State University, Raleigh, 27695, USA.
}

ABSTRACT - Sows produce a larger number of fetuses than before and these fetuses possess genetic potentials to grow faster than before. Recent comparison shows that a porcine fetus is $40 \%$ heavier than 40 years ago. Thus the nutritional management of sows has been updated to reflect these genetic changes. Our recent study quantified nutritional needs for sows to support the growth of fetuses and mammary glands during gestation. Amino acid needs for fetal growth and mammary growth during late gestation (d 70 to farrowing) significantly greater than those needs during early gestation (until d 70). Considering these increases, daily requirement of true ileal digestible Lys for a primiparous sows increases from $7 \mathrm{~g}$ (until d 70 ) to $15 \mathrm{~g}$ (d 70 to farrowing). Required qualities of proteins (i.e., amino acid ratios) also change with an advance of pregnancy as maternal, fetal, and mammary tissues have their unique amino acid compositions. Thus, if the feed does not provide sufficient amounts and qualities of proteins, sows can be under a severe catabolic status during late gestation, especially during late gestation. Sows under a conventional feeding program had increased litter weight variations at farrowing (19\%) compared with early gestation (3.0\%). Our recent study also shows that sows under a conventional feeding program have a dramatic increase in a systemic oxidative stress during late gestation compared with early gestation when measured by plasma $\alpha$-tocopherol (56\% decrease), plasma retinol (57\% decrease), and DNA damage in white blood cells (125\% increase) which were sustained until the early lactation period. Increased oxidative damages in sows negatively affect the growth and health of fetuses as well as postpartum growth. Sow feeding during late gestation should reflect the changed needs for amino acids and antioxidants. Phase feeding or top dressing could be a practical solution to provide sufficient nutrients during late gestation.

Key Word: amino acids, fetus, gestation, lactation, oxidative stress, sows

\section{Recentes avanços na nutrição de porcas}

RESUMO -Matrizes produzem maior número de fetos que antes, e esses fetos possuem potencial genético para crescer mais rapidamente que antes. Comparação recente mostra que um feto suíno é $40 \%$ maior que há 40 anos. Assim, o manejo nutricional das fêmeas foi atualizado para refletir essas alterações genéticas. Nosso estudo recente quantificou as necessidades nutricionais de porcas para suportar o crescimento do feto e da glândula mamária durante a gestação. Aminoácidos são mais necessários para o crescimento fetal e crescimento mamário durante a gestação tardia (d 70 a parição) do que durante a gestação precoce (até 70 d). Considerando estes aumentos, a exigência diária de lisina digestível ileal verdadeira de porcas primíparas aumenta de $7 \mathrm{~g}$ (até 70 d) a 15 g (70 d a parição). Qualidades de proteínas exigidas (ou seja, relação de aminoácidos) também mudam com antecedência de gravidez, como materno e fetal, e tecidos mamários têm suas próprias composições de aminoácidos. Assim, se a alimentação não fornecer quantidade suficiente e qualidade de proteínas, as fêmeas podem estar sob severo estado catabólico durante a gestação tardia. Matrizes sob um programa de alimentação convencional apresentaram variações no peso ao parto (19\%) em comparação à gestação precoce (3,0\%). Nosso estudo recente também mostra que as porcas sob um programa de alimentação convencional apresentaram aumento severo de estresse oxidativo sistêmico na gestação tardia em comparação à gestação precoce, quando medido por plasma alfa-tocoferol (diminuição de 56\%) e retinol plasmático (redução de 57\%), e dano de DNA em células brancas do sangue (aumento de 125\%), que foram mantidas até o período de lactação. Aumentos de danos oxidativos em porcas afetam negativamente o crescimento e a saúde dos fetos, bem como o crescimento pós-parto. A alimentação de porcas durante a gestação tardia deve refletir as necessidades de mudança para aminoácidos e antioxidantes. A fase de alimentação ou cobertura poderia ser uma solução prática para fornecer nutrientes suficientes durante a gestação tardia.

Palavras-chave: aminoácidos, feto, gestação, lactação, estresse oxidativo, porcas 


\section{Introduction}

Continuous genetic selection of pigs improved sows for high prolificacy and for producing high lean progeny. As consequences, modern sows produce larger litters than those decades ago (Kim, 1999) which are leaner and growing faster (McPherson et al., 2004). Recent comparison shows that a porcine fetus is $40 \%$ heavier than 40 years ago (Figure 1). However, selection of pigs for high leanness also resulted in high lean type sows possessing a low appetite (Kanis, 1990; Kim et al., 2005).

Although these genetic selections have benefitted swine industry by improving efficiency of production, sows face tremendous metabolic stresses to provide nutrients for supporting the growth of fetal tissues (McPherson et al., 2004), mammary parenchymal tissues (Kim et al., 1999; Ji et al., 2006), and milk synthesis (Revell et al., 1998; Jones \& Stahly, 1999) under the condition of a limited nutrient intake and a limited capacity of maternal tissue mobilization. Severe metabolic burdens to sows lead to poor subsequent reproductive performance, and early culling (Kirkwood et al., 1987; Revell et al., 1998).

Conventional feeding program has been implemented to prevent obesity during gestation and encourage feed intake during lactation. However, this program has not been successful fully providing accurate nutrients meeting the needs for sows especially during late gestation and lactation. Recently, efforts have made to evaluate metabolic stress levels under conventional feeding program and also to reevaluate nutritional requirements of sows during pregnancy and lactation. The objective of this article is to review recent advances in nutritional strategies to enhance productivity and health of sows.

\section{Principles of feeding management}

The nutritional status of sows at farrowing directly affects performance during lactation. Causing obesity at farrowing can result in reduced voluntary feed intake and, therefore, increased weight loss during lactation (Lodge et al., 1966; Baker et al., 1969; Sinclair et al., 2001). Young sows undergoing first and second parities can have greater impact by low voluntary feed intake than for mature sows. In the meantime, severe restriction in energy intake during gestation can result in thin sows at farrowing, which causes problems with lactation for reduced milk productions and litter weaning weights. In order to control energy intake of gestating sows, restrict feeding in individual crates is a common practice. However, feed restriction can also limit intake of other nutrients including protein and minerals causing protein deficiency, especially during late gestation and lactation. Thus, considering limited feed allowance for energy restriction, it is important to provide a diet that permits allowance of other nutrients meeting the requirements.

\section{Current problems}

Conventional feeding program for gestating sows does not provide sufficient proteins and minerals during late gestation causing increased metabolic stress to sows. Typical corn soybean meal based diets are formulated to provide 8 to $11 \mathrm{~g}$ true ileal digestible (TID) Lys daily to sows

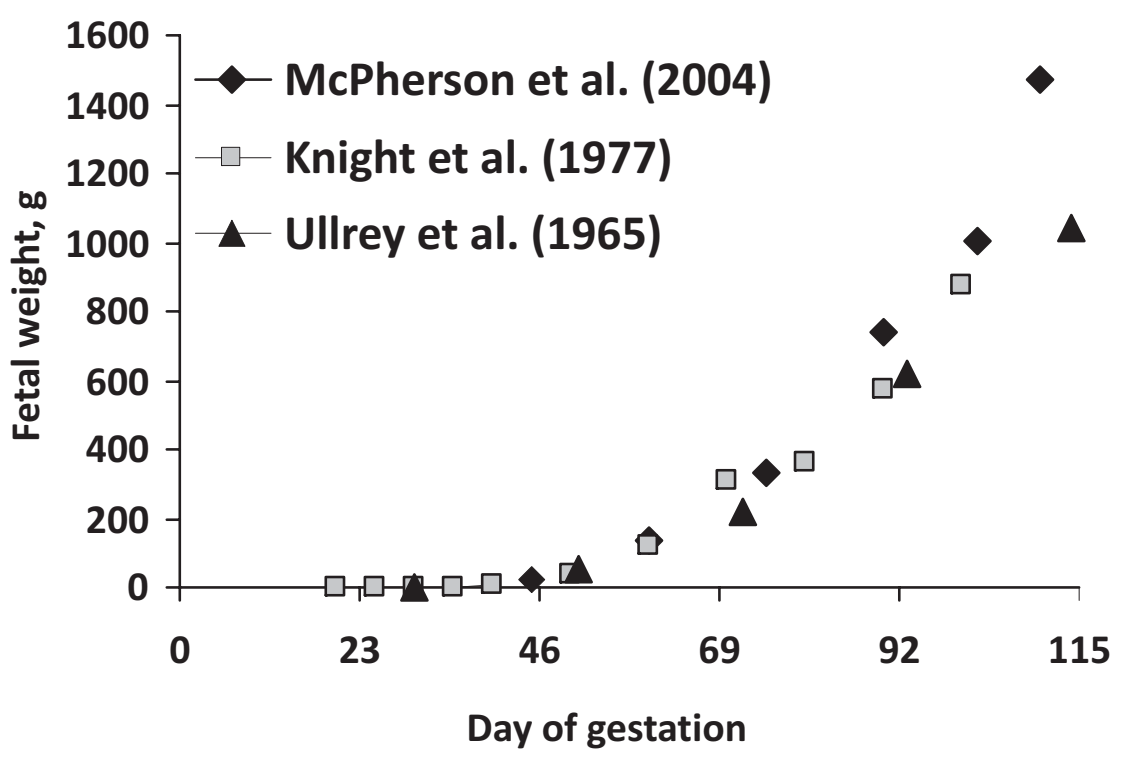

Figure 1 - Growth patterns of porcine fetus. Data were adapted from Ullrey et al. (1965), Knight et al. (1977) and McPherson et al. (2004). 
during the entire gestational period. Our recent study (Kim et al., 2009) shows that conventional feeding program providing 8 to $11 \mathrm{~g}$ TID Lys would significantly underfeed Lys during late gestation as requirements of TID Lys increase from $6.8 \mathrm{~g} / \mathrm{d}$ to $15.3 \mathrm{~g} / \mathrm{d}$ during late gestation (Figure 2). This increase in Lys requirement is due to dramatic changes in fetal tissue gain from 0.25 to $4.63 \mathrm{~g} \mathrm{CP} /$ d/fetus (McPherson et al., 2004) and mammary tissue gain from 0.41 to $3.41 \mathrm{~g} \mathrm{CP} / \mathrm{d} /$ gland (Ji et al., 2006) from early to late gestation (Figure 3 and 4).

There are several evidences supporting that sows are not providing sufficient nutrients to fetal and mammary growth during late gestation. We have shown that weight variations expressed as a coefficient of variation (\%) among the weights of fetuses in each litter were smaller on d 45 of gestation than those on later than d 60 of gestation (Kim et al., 2009). This indicates that fetal growth retardation occurs mainly from d 60 of gestation (Figure 5). Interestingly, fetal weight linearly decreased for fetuses nearer the cervix to those nearer the distal locations on uterine horn on d 102 and 112 of gestation whereas there were no correlations between fetal weight and fetal location on d 30 and 60 of gestation (Figure 6). Limited nutrient supply from sows to support the growth of fetuses increased fetal weight variation during late gestation indicating that the current feeding program for gestating sows is suboptimal for fetal growth especially during late gestation.

\section{The true ileal digestible lysine needs of gilts before and after $\mathrm{d} 70$ of gestation $(\mathrm{g} / \mathrm{d})$}

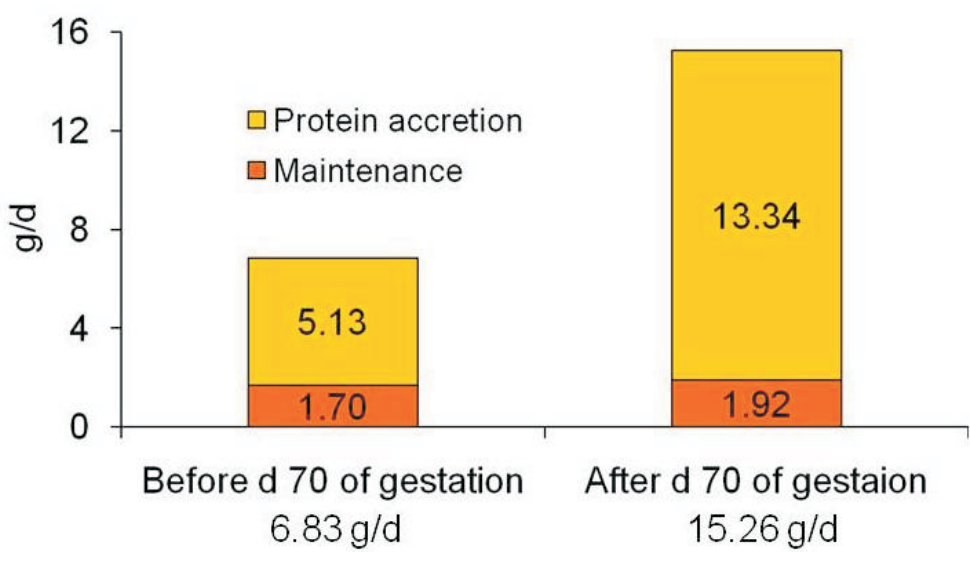

Figure 2 - Requirements of true ileal digestible Lys of sows during early and late gestation.
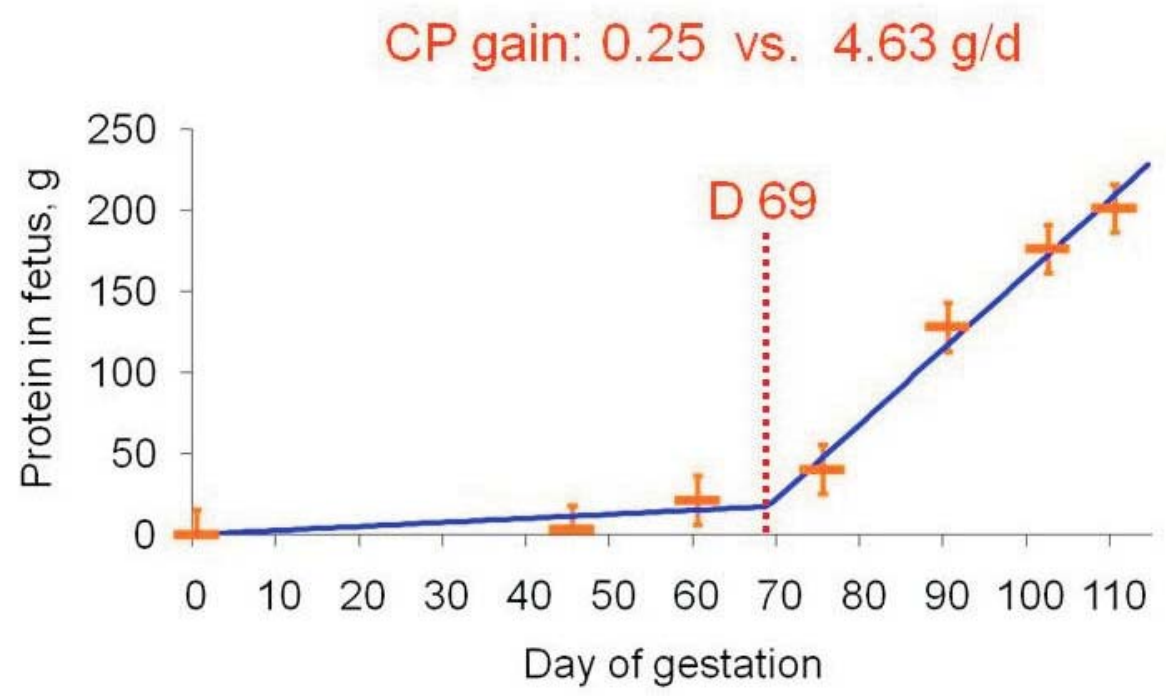

Figure 3 - Protein content in a fetus during gestation. Adapted from McPherson et al. (2004). 


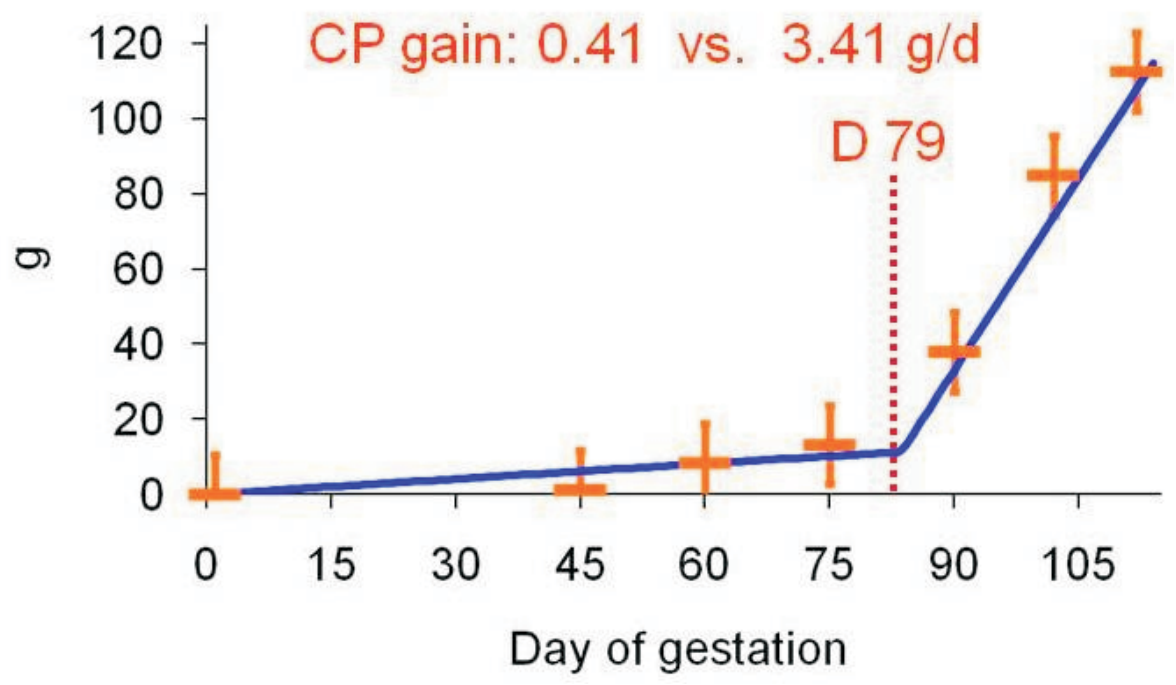

Figure 4 - Protein content in a mammary gland during gestation. Adapted from Ji et al. (2006).

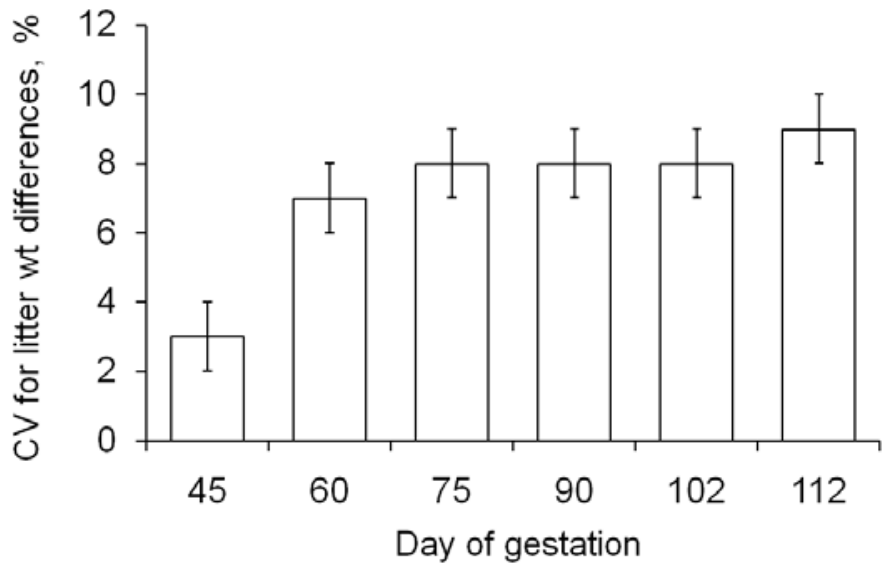

Figure 5 - Weight variations among fetuses within a litter on different days of gestation. Litter weight variation was expressed as coefficient of variation [CV (\%)] for each litter on different days of gestation. Adapted from Kim et al. (2009).

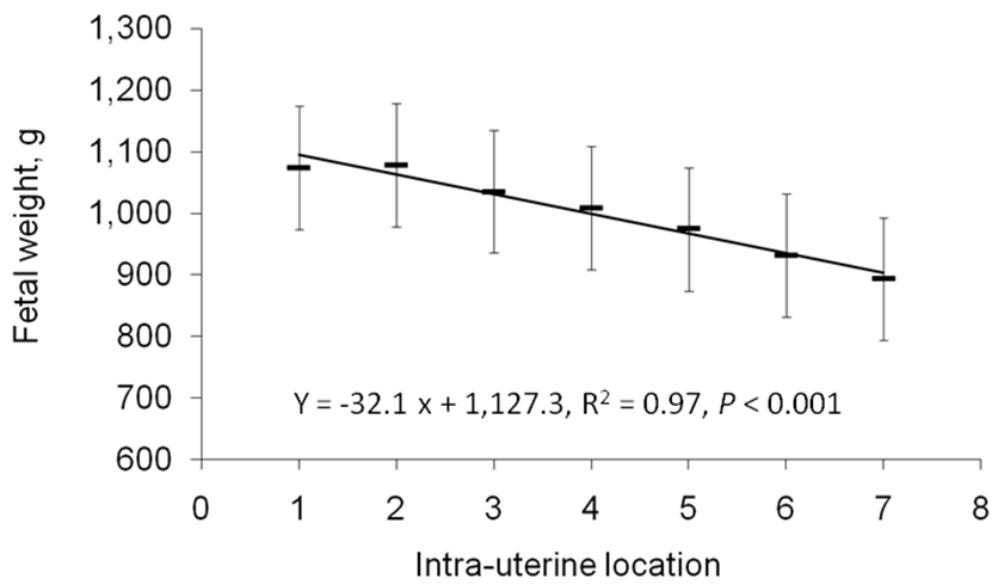

Figure 6 - Litter weight variations among fetuses on d 102 of gestation. Intra-uterine location 1 indicates anterior (i.e., toward the uterotubal junction) extremity and 7 indicates posterior (i.e., toward the cervix) extremity. Adapted from Kim et al. (2009). 
Recently, we demonstrated that sows are under severe catabolic status during late gestation causing increased oxidative stress (Berchieri-Ronchi et al., 2010). Plasma $\alpha$ tocopherol and retinoid concentrations were lower by 56 and $57 \%$ at d 110 of pregnancy as compared with d 30 of pregnancy, respectively (Figure 7). Lymphocyte DNA damage was analyzed by alkaline single cell gel electrophoresis (comet assay) showing increased endogenous DNA damage during late gestation by $125 \%$ compared with d 30 of pregnancy (Figure 8). These results clearly show that sows undergo increased damage to immune cells due to increased oxidative stress to DNA and increased systemic oxidative damage due to reduced antioxidative capacity. It seems that oxidative stress to sows increases when sows are under environmental stress such as heat stress and social stress. Sows under heat stress environment showed increased oxidative stress by increased lipid peroxidation, protein oxidation, and oxidative DNA damage compared with the sows under comfort thermal neutral zone. Sows in a gestation stall seem to have increased oxidative stress compared with sows in a group pen environment. Increased oxidative damages in sows during late pregnancy would negatively affect the growth and health of fetuses as well as postpartum growth of piglets.

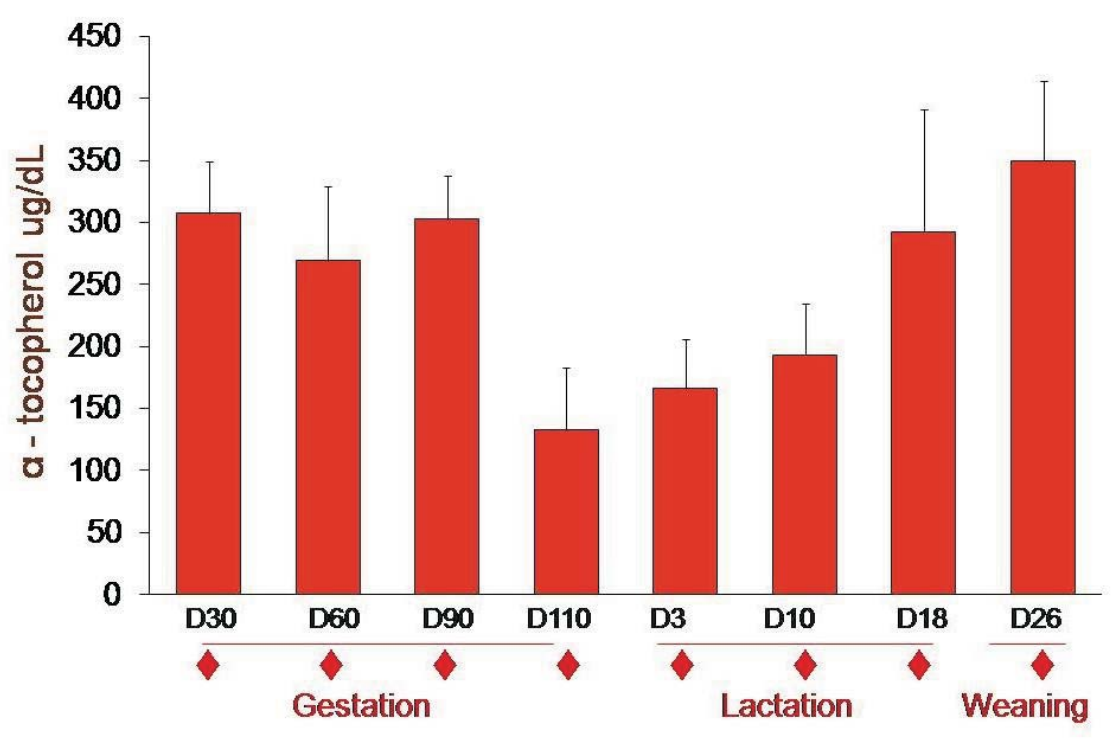

Figure 7 - Plasma $\alpha$-tocopherol concentration during gestation and lactation. Adapted from Berchieri-Ronchi et al. (2010).

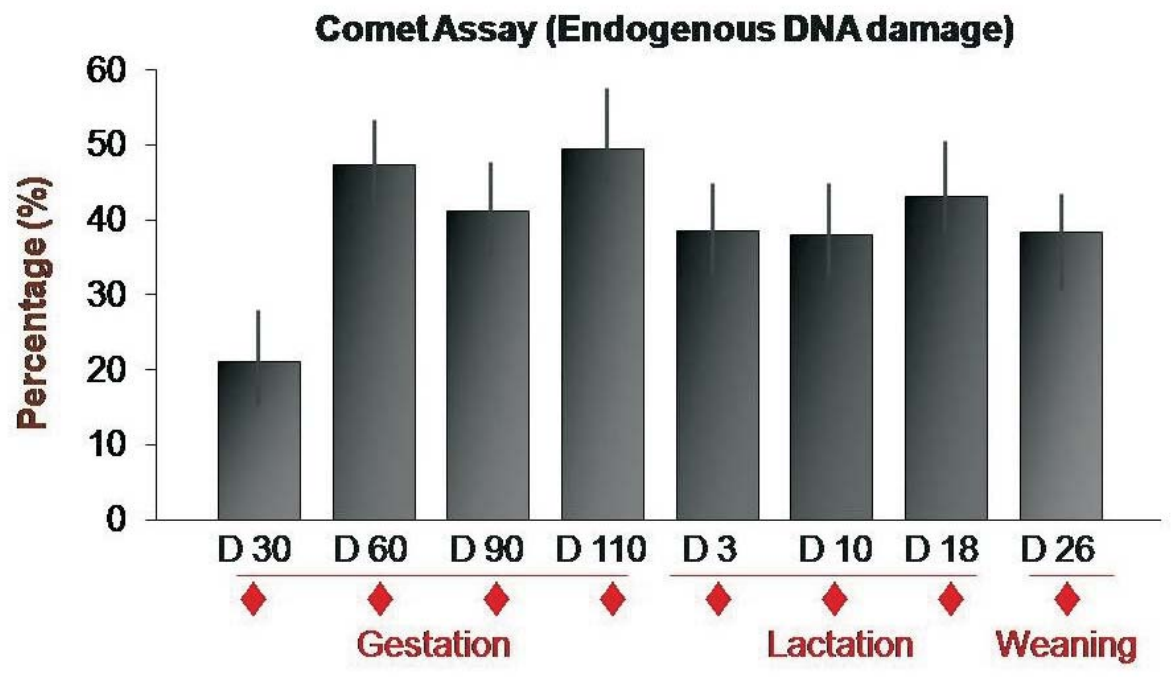

Figure 8 - Lymphocyte endogenous DNA damage (comet assay) during gestation and lactation. Adapted from Berchieri-Ronchi et al. (2010). 


\section{Nutritional management of sows}

Based on findings discussed above, we propose that sow feeding during late gestation should reflect the changed needs for amino acids and antioxidants because a proper feeding during late gestation will eventually help producing uniform and healthy piglets. Currently available recommended dietary amino acid requirements for pregnant sows (NRC, 1998) are based on studies with growing pigs (Mahan \& Shields, 1998) and considered to be constant throughout gestation (NRC, 1998). However, amino acid requirements of gestating sows are expected to vary greatly with gestation stage. Considering that protein accretion rate in fetal and mammary tissues increases (McPherson et al., 2004; Ji et al., 2005) and amino acid composition in fetal pigs and mammary gland changes with gestation (Kim et al., 2009), a constant amino acid content and ratio in the diet for gestating sows seems unreasonable. Kim et al. (2009) provides details on amino acid requirements and ideal ratio for gestating sows suggesting phase feeding during gestation to accommodate changes in requirements for amino acids (Table 1). Considering changes in oxidative damage status during gestation, sows' need for antioxidants would significantly increase during late gestation which can also be factored in phase feeding. Our recent studies also show that fetal growth can be help by improving nutrient supply to fetuses through dietary supplementation of arginine (Mateo et al., 2007; Figure 9) and omega-3-series fatty acids (Mateo et al., 2009; Figure 10).

Table 1 - Requirements of true ileal digestible amino acid and ideal dietary amino acid ratios for sows during gestation. Adapted from Kim et al. (2009)

\begin{tabular}{|c|c|c|c|c|c|c|c|c|}
\hline & & & Am & true il & stible & & & \\
\hline & Lys & Thr & Val & Leu & Ile & Phe & Arg & His \\
\hline D 0 to 60 of gestation & & & & & & & & \\
\hline Amount, g/d & 5.57 & 4.42 & 3.62 & 4.92 & 3.26 & 2.79 & 4.97 & 2.00 \\
\hline Ratio relative to Lys, \% & 100.0 & 79.4 & 65.0 & 88.3 & 58.6 & 50.1 & 89.3 & 35.9 \\
\hline D 60 to 114 of gestation & & & & & & & & \\
\hline Amount, g/d & 8.78 & 6.25 & 5.83 & 8.36 & 4.87 & 4.54 & 8.59 & 3.12 \\
\hline Ratio relative to Lys, \% & 100.0 & 71.2 & 66.4 & 95.3 & 55.5 & 51.8 & 97.9 & 35.5 \\
\hline
\end{tabular}

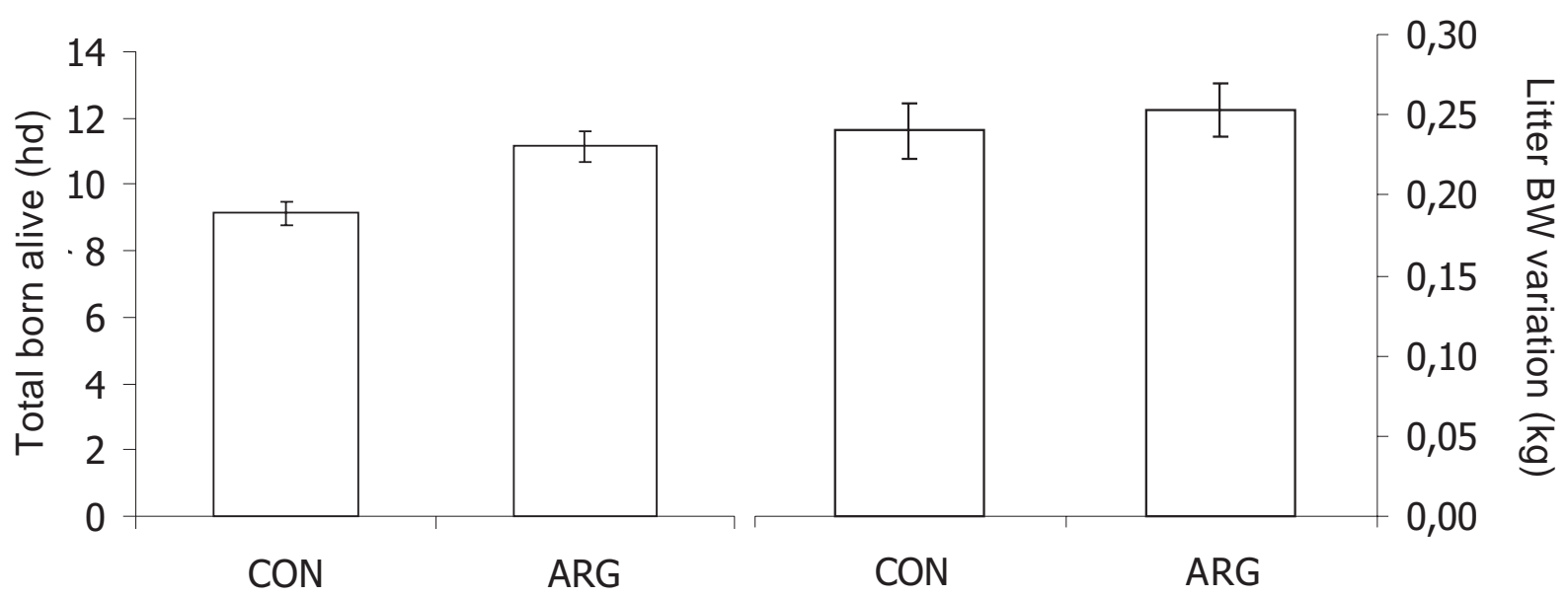

Figure 9 - Number of total born alive and their weight variation at birth (kg) from sows fed diets supplemented with or without $1 \%$ L-arginine HCl. Data were adapted from Mateo et al. (2007). 


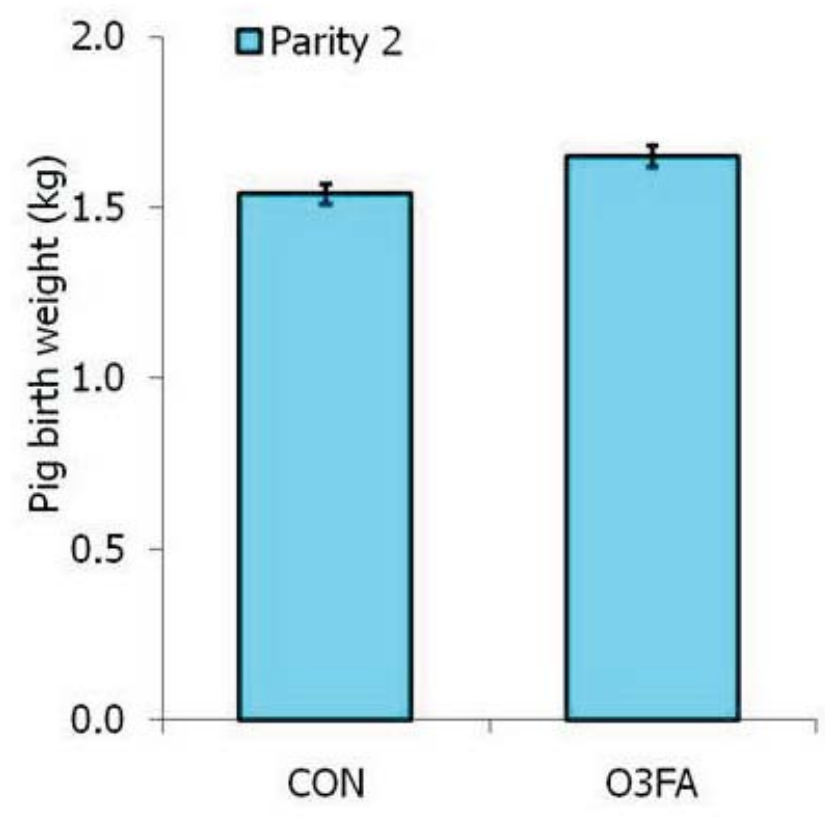

Figure 10 - Birth weight of pigs from sows fed diets supplemented with omega-3-series fatty acids over two parties. Adapted from Mateo et al. (2009).

\section{Conclusions}

With improvements in genetic potential of sows producing a larger number of fetuses with genetic potentials to grow faster than before, sows need increased amount of nutrients to support the growth of fetuses. Current feeding program provides deficient amount of proteins to sows causing increased fetal weight variation and increased metabolic and oxidative stresses to sows. With our recent investigations, it is suggested that we need to increase daily protein intake. For example, the requirements of true ileal digestible lysine would be $15 \mathrm{~g} / \mathrm{d}$ and those of other essential amino acids can follow the ideal amino acid ratio to lysine. Sows would also need increased dietary antioxidants to cope with $56 \%$ decrease of plasma $\alpha$-tocopherol, $57 \%$ decrease of plasma retinol, and $125 \%$ increase of DNA damage in white blood cells during late gestation which were sustained until the early lactation period. Increased oxidative damages in sows negatively affect the growth and health of fetuses as well as postpartum growth. Sow feeding during late gestation should reflect the changed needs for amino acids and antioxidants. Phase feeding or top dressing could be a practical solution to provide sufficient nutrients during late gestation.

\section{References}

BAKER, D.H.; BECKER, D.E.; NORTON, H.W. et al. Reproductive performance and progeny development in swine as influenced by feed intake during pregnancy. Journal Nutrition, v.97, p.489-495, 1969.

BERCHIERI-RONCHI, C.B.; ZHAO, Y.; CORREA, C.R. et al. Oxidative stress status of high prolific sows during pregnancy and lactation. The FASEB Journal, 2010 (Abst.).

JI, F.; WU, G.; BLANTON JR., J.R. et al. Changes in weight and composition in various tissues of pregnant gilts and their nutritional implication. Journal of Animal Science, v.83, p.366-375, 2005.

JI, F.; HURLEY, W.L.; KIM, S.W. Characterization of mammary gland development in pregnant gilts. Journal of Animal Science, v.84, p.579-587, 2006.

JONES, D.B.; STAHLY, T.S. Impact of amino acid nutrition during lactation on body nutrient mobilization and milk nutrient output in primiparous sows. Journal of Animal Science, v.77, p.1513 1522, 1999.

KANIS, E. Effect of food intake capacity on genotype by feeding regimen interactions in growing pigs. Animal Production, v.50, p.343-351, 1990.

KIM, S.W. Mammary gland growth and nutrient mobilization in lactating sows: a dynamic model to describe nutrient flow. 1999. Thesis (Ph.D.) - University of Illinois at Urbana - Champaign, IL.

KIM, S.W.; HURLEY, W.L.; WU, G. et al. Ideal amino acid balance for sows during gestation and lactation. Journal of Animal Science, v.87, p.E123-E132, 2009.

KIM, S.W.; WU, G.; BAKER, D.H. Amino acid nutrition of breeding sows during gestation and lactation. Pig News Info. CABI, v.26, p.89N-99N, 2005.

KIM, S.W.; HURLEY, W.L.; HAN, I.K. et al. Changes in tissue composition associated with mammary gland growth during lactation in the sow. Journal of Animal Science, v.77, p.2510-2516, 1999a.

KIRKWOOD, R.N.; LYTHGOE, E.S.; AHERNE, F.X. Effect of lactation feed intake and gonadotrophin-releasing hormone on the reproductive performance of sows. Canadian Journal of Animal Science, v.67, p.715-719, 1987.

KNIGHT, J.W.; BAZER, F.W.; THATCHER, W.W. et al. Conceptus development in intact and unilaterally hysterectomized-ovariectomized gilts: Interrelations among hormonal status, placental development, fetal fluids and fetal growth. Journal of Animal Science, v.44, p.620636, 1977.

LODGE, G.A.; ELSLEY, F.W.H.; MACPHERSON, R.M. The effects of level of feeding of sows during pregnancy. II. Changes in body weight. Animal Production, v.8, p.499-507, 1966.

MAHAN, D.C.; SHIELDS JR., R.G. Essential and nonessential amino acid composition of pigs from birth to 145 kilograms of body weight, and comparison to other studies. Journal of Animal Science, v.76, p.513-521, 1998.

MATEO, R.D.; WU, G.; BAZER, F.W. et al. Dietary L-arginine supplementation enhances the reproductive performance of gilts. Journal Nutrition, v.137, p.652-656, 2007.

MATEO, R.D.; CARROLL, J.A.; HYUN, Y. et al. Effect of dietary supplementation of omega-3 fatty acids and high protein on reproductive outcome of primiparous sows for two parities. Journal of Animal Science, v.87, p.948959, 2009.

McPHERSON, R.L.; JI, F.; WU, G. et al. Growth and compositional changes of fetal tissues in pigs. Journal of Animal Science, v.82, p.2534-2540, 2004. 
NATIONAL RESEARCH COUNCIL - NRC. Nutrient requirements of swine. 10.ed. Washington, D.C.: National Academy Press, 1998.

REVELL, D.K.; WILLIAMS, I.H.; MULLAN, B.P. et al. Body composition at farrowing and nutrition during lactation affect the performance of primiparous sows: II. Milk composition, milk yield, and pig growth. Journal of Animal Science, v.76, p.1738 1743, 1998.
SINCLAIR, A.G.; BLAND, V.C.; EDWARDS, S.A. The influence of gestation feeding strategy on body composition of gilts at farrowing and response to dietary protein in a modified lactation. Journal of Animal Science, v.79, p.2397 2405, 2001.

ULLREY, D.E.; SPRAGUE, J.L.; BECKER, D.E. et al. Growth of the swine fetus. Journal of Animal Science, v.24, p.711717, 1965. 